\title{
University renames faculty after row over eugenics advocate
}

Paris. The board of the University of Claude Bernard in Lyons, France, has voted to remove from its faculty of medicine the name of Alexis Carrel, winner of the Nobel prize for physiology or medicine in 1912, whose reputation has recently come under fire for his support of eugenics in the years before the Second World War, and for his alleged links with the collaborationist Vichy regime (see Nature 378, 122; 1995).

But as one controversy abates, a related dispute has been opened up by the announcement by a historian at the Centre Nationale de la Recherche Scientifique that he intends to sue Presses Universitaires de France (PUF), one of France's leading academic publishers, for refusing to publish an article that it commissioned from him about Carrel.

Forty-six of the 59 members of the board of the Lyons university voted in favour of removing Carrel's name, which the university hopes will end the bitter con- Carrel: name replaced troversy between by that of Laennec. the supporters and

opposers of such an act. The university intends to rename the faculty $\mathrm{RTH}$ Laennec, after the less controversial René Théophile Hyacinthe Laennec (1781-1826), who invented the stethoscope and pioneered research on lung and liver disorders.

The complaint against PUF has been made by Alain Drouard, an expert on Carrel who has long argued that the biologist's eugenic views have been taken out of their historical context, in particular the widespread support for eugenic ideas among scientists in the $1930 \mathrm{~s}$.

Drouard's article was to have appeared in the three-volume Dictionnaire du Darwinisme et de L'Évolution, published last month. But Patrick Tort, the encyclopaedia's editor and an outspoken critic of Carrel, replaced Drouard's article with one of his own.

Tort claims he was merely exercising his right as an editor, and says he rejected the article because he felt its conclusions constituted "unacceptable" revisionism. But Drouard, who argues that PUF has broken a contract made with him in 1991, accuses Tort of "ideological censorship" as well as of infringing academic liberty and free speech.

Ironically, while Tort now argues that Drouard's paper was of "bad quality", he wrote to Drouard in 1991 saying that although the article was somewhat "kind" to Carrel, it was nonetheless "excellent". D.B.

\section{French citations forge ahead but Europe still loses ground}

Paris. France's share of papers appearing in international scientific journals increased by 14 per cent over the period 1982 to 1993 , a rise that appears to reflect both increased research spending under the late President François Mitterrand and the increasing number of French scientists publishing in English. In contrast, Germany's share during this period decreased by 4 per cent, and that of the United Kingdom by 7 per cent.

But in overall figures, French publications still lag behind those of its two main European competitors, according to the 500-page third report of the Paris-based Observatoire des Science et des Techniques (OST). In 1993, for example, France was responsible for 4.9 per cent of the total number of international scientific papers, compared with 6.2 per cent for Germany and 8.5 per cent for the United Kingdom.

Furthermore, these figures mask much greater swings within individual disciplines. For example, although the United Kingdom maintains a strong position in biomedicine, accounting for 12.4 per cent of all international publications, its share of papers in applied biology and ecology fell by 22 per cent, and those in mathematics by 21 per cent. In contrast, France's share of mathematics papers increased by 59 per cent, from 4.2 to 6.7 per cent of the total.

Within Europe, the greatest gains have been registered by those countries that started from a lower base. For example, both Spain and Portugal more than doubled their share of total international scientific publications by member states of the European Union, to 5.6 per cent and 0.4 per cent respectively. Italy increased its share from 7.6 to 9.3 per cent.

One explanation for France's growing share of international scientific publications is the rejuvenation of French science under the government of Mitterrand, when public spending on research increased from 1.97 per cent of gross national product to 2.4 per cent at the end of the 1980s. (OST cautions, however, that funding for French science has "stagnated" since 1990.)

At the same time, France's increased share may also partly reflect a trend to publish more in English, in particular in mathematics. In 1982, 68.1 per cent of articles published by French scientists in journals included in the Science Citation Index, published by the Institute for Scientific Information in Philadelphia were in English; this figure has now risen to 81 per cent.

Furthermore, only 73.3 per cent of articles published by French scientists in French journals are now in French, compared with 84.5 per cent in 1982 . They may have good reason to prefer publishing in English; according to OST, French scientific journals that are published either partially or totally in English have an impact factor 3.5 times higher than those published in French alone.

In global terms, the OST report shows that the European Union (EU)'s share of the world's international scientific publications, based on a variety of sources that includes in particular articles cited in the Science Citation Index, increased by 7 per cent, to 31.4 per cent of the total, between 1982 and 1993. Over the same period, the US share of the total fell by 4 per cent (to 35.5 per cent), while Japan increased its share by 19 per cent (to 8 per cent).

Perhaps the most striking changes over this same period are the halving of the former Soviet Union's share, from 8.4 to 4.8 per cent of the total, and the quadrupling of the shares of both China ( 0.3 to 1.2 per cent) and the emerging economies of South-East Asia (0.3 to 1.4 per cent).

The report also confirms that Europe is losing ground to the United States and Japan in key areas of technology, at least measured in terms of patents. The strongest growth in technology has occurred in Japan and South-East Asia. But the United States still accounts for half the world's 'technological activity' - calculated by OST partly on the basis of the levels of public and private financing of research - in pharmaceuticals, computing and biotechnology.

In contrast, and using the same yardstick, Europe has generally fallen behind in key technologies, in particular in computing and telecommunications, although it has made progress in areas such as aerospace, pharmaceuticals and instrumentation.

Within Europe, Germany accounts for 37.6 per cent of the total of European patents taken out by EU countries in key areas of technology. France holds 23.6 per cent, and the United Kingdom 15.7 per cent. France leads in computing with a 29.7 per cent share. Moreover, the share of European patents taken out by EU countries in all areas has fallen by 9 per cent to 49.5 per cent over the decade. In contrast, the US share increased by 6 per cent (to 28.1 per cent), while that of Japan jumped by 22 per cent.

Within Europe, France's share increased from 17.3 to 18.1 per cent between 1987 and 1993. Over the same period, Germany's share remained stable at around 43 per cent, while the UK share fell by 17 per cent to 12.4 per cent. In terms of US patents taken out by EU countries, France's share increased from 15.8 to 17.7 per cent, whereas Germany's share fell by 10 per cent to 42.4 per cent, and the UK's share by 24 per cent to 14.3 per cent.

Declan Butler 